\title{
The Unitary Patent Package: Twelve Reasons for Concern
}

The proposed Unitary Patent Package currently under discussion consists of (see Annex 1)

- a Regulation on the European patent with unitary effect (unitary patent, UP Regulation); ${ }^{1}$

- an Agreement on a Unified Patent Court for litigation on infringements and revocation of European and unitary patents (UPCt Agreement). ${ }^{2}$

This package stands in a long tradition of proposals for patent reform in Europe. However, compared to previous approaches, the current one represents a significant step back in terms of patent law quality and legal viability. Moreover, it misses the opportunity to modernize Europe's system of patent protection.

Our main observations are grouped under three main headings: Complexity of the regime, imbalances in the system, and lack of legal certainty for investments in innovation. ${ }^{3}$

\section{The unitary patent package adds to complexity}

1. Fragmentation of patent protection in the EU. Instead of consolidating patent law in Europe, the Unitary Patent Package would add to its fragmentation on both the territorial and substantive level.

a. Territorial fragmentation: The unitary patent would not cover the full territory of the Internal Market. It is restricted to EU Member States participating in enhanced cooperation. In addition, it will become operable only for those Member States which ratify the UPCt Agreement. Thirteen ratifications are required. Accordingly, not all 25 signatory States need to ratify and it is even unlikely that all will do so in the foreseeable future. From the EU perspective, this fragments the Internal Market and runs counter to the cohesion objective. From the perspective of patent holders, the lack of patent protection in major European markets (at least Italy and Spain) jeopardizes innovation there. Thus, the unitary patent would need to be flanked by national patents.

b. Substantive fragmentation: The Unitary Patent Package would create four overlapping levels of patent protection in Europe (see Annex 2; not counting utility model protection):

(1) national patents granted nationally;

(2) national patents granted by the EPO (European patents) within the system of the UPCt Agreement;

(3) national patents granted by the EPO, but without subjection to the UPCt (due to transitional opt-out, non-ratification by Member States, or for non-EU States);

(4) European patents with unitary effect.

According to the principle of optionality, all systems would coexist alongside each other. 
2. Fragmentation in the rules applicable to the unitary patent. A patent grants a right of exclusivity. This serves to protect against infringers; it may also serve as an asset. Arts. 6 to 8 of the UP Regulation provide for a broad, albeit not complete set of rules on infringement and on its exceptions.

By contrast, as regards the unitary patent as an object of property, the UP Regulation contains only a very truncated set of rules. Basic rules, as contained in all previous proposals (transfer of right, rights in rem, treatment in execution and insolvency, erga omnes effect of restrictive contractual licensing, date of third-party effects of patent transactions), are missing. Instead, Art. 10 of the UP Regulation provides for the exclusive application of national law.

This means that to a given unitary patent only one national law would apply throughout the territories of enhanced cooperation. Yet it also means that different national laws would apply to different unitary patents. Therefore, instead of creating uniformity, a multiplicity of national laws would apply. While some reference to national law is inevitable as a matter of implementing the property rules of patents, the UP Regulation misses an opportunity to provide for a minimum of uniformity and transparency for market actors.

3. Fragmentation of jurisprudence. The fragmentation on the level of the substantive law is mirrored by a proliferation of courts which would be competent to interpret and apply patent law in Europe under the proposed court system (see Annex 3). Jurisdictional competences would lie with

(1) the UPCt in respect of infringements and validity of European and unitary patents for those Member States which have ratified the UPCt Agreement;

(2) the ECJ in respect of preliminary references from the UPCt regarding infringements of unitary patents;

(3) national courts of EU Member States not ratifying the UPCt Agreement or not participating in enhanced cooperation and those of all non-EU EPO Contracting States regarding infringements and validity of national and European patents;

(4) the EPO's Boards of Appeal in administrative appeals for European patents;

(5) national courts or administrative bodies in proceedings regarding nationally granted patents.

Under each of these alleys, similar principles of patent law might be elaborated differently, and different layers of substantive rules applied (see Annex 2). The UPCt Agreement does not provide for any method of consolidation. The Agreement simply adds an additional enforcement layer alongside the pre-existing.

\section{The unitary patent package is unbalanced}

4. Insufficient exceptions and limitations. The substantive rules laid down in the UP Regulation respond in no way to the modern challenges to patent law. Unlike, for example, Belgian law or the recently reformed Swiss Patent Act, the Regulation does not address issues such as a general research exception or compulsory licenses for biotechnological research tools. 
5. Absence of countervailing rights. The UP Regulation no longer contains rules on prior user rights and on compulsory licenses for enabling the use of dependent improvement inventions or in the public interest. This perpetuates and entrenches anti-innovative effects in patent protection. Prior user rights are not available at all. Compulsory licenses are assumed to be available under national law only, if at all (see reason 11). However; the application of 25 Member States' divergent standards jeopardizes the unitary effect. In addition, the unavailability of Union-wide compulsory licenses at uniform conditions places third parties seeking access to patented technology at a significant disadvantage compared to the improved possibility of the unitary patent holder to enforce the patent right before one single court.

6. Risk of dysfunctional patent practices. The insufficiency of exceptions and limitations as well as the absence of countervailing rights in the UP Regulation render the unitary patent prone to "opportunistic" behaviour. For instance, patent applicants may tend to seek protection for key aspects of a technology by unitary patents while selectively relying on national patent protection for other components of the technology. This would bring the overall system of protection out of balance and may stifle broader innovation.

7. Discriminatory effects. Art. 10 of the UP Regulation, which provides for the application of one national law to the unitary patent as an object of property (see reason 2; also Annex 2), entails discriminatory effects. According to Art. 10(3) of the Regulation, patents which have been applied for by firms without a residence or place of business in one of the Member States participating in enhanced cooperation, will be subject to a foreign law, namely to German law. By contrast, patent applicants established in one of the participating States will benefit from the application of their domestic law.

8. Inherent ineffectiveness of the Unified Patent Court. The design of the UPCt (see Annex 3) is dysfunctional. This would hamper the UPCt's effectiveness. In broad terms, these flaws can be subdivided into three groups:

(1) imbalances in the scope of jurisdiction (e.g. no jurisdiction for compulsory licenses, territorial jurisdiction limited to EU Member States, differing judicial review for European and unitary patents, etc.);

(2) imbalances in the division of jurisdiction among the first instance divisions (e.g. questionable effects of the compromise on bifurcation, reserved competences of the central division, etc.);

(3) imbalances in the organization of the UPCt (e.g. predominantly national composition of the bench in large decentralized divisions, language regime, etc.).

All of this would likely impair the development of a homogeneous body of patent law in Europe, fail to establish a fair balance in the rights and remedies available to patent holders and third parties respectively, and open the system to continued forum shopping by plaintiffs. 


\section{The unitary patent package lacks legal certainty}

9. Uncertain implications of the unitary effect. The shift from a unitary and autonomous EU patent right to the hitherto unknown, hybrid creature of a "European patent with unitary effect" casts doubts on the legal quality of the patent protection thereby afforded.

a. Legal nature of the unitary patent. Under the proposal, the unitary effect seems to be attached to a European patent only as an accessory feature. This obscures the legal character of the unitary patent (international law, EU law or a new sui generis right?). However, the unitary effect concerns the substance of the right of exclusivity. In this regard, only EU law can guarantee an autonomous and supranational character and a complete and coherent system of legal protection for individuals.

b. Multi-layered legal structure. The European patent with unitary effect is split into different layers of international law, EU law and national law. The cross effects between these layers are unclear. Examples include the reach of EU law primacy vis-à-vis the EPC or the role of national law vis-àvis the UP Regulation. The complexity would even be reinforced should the substance of protection become hidden behind a system of legal referrals replacing Arts. 6 to 8 of the UP Regulation, as is currently discussed as a compromise formula.

10. Incorrect legal basis for the unitary patent. Art. 118(1) TFEU provides a legislative basis for the "creation of European intellectual property rights to provide uniform protection of intellectual property rights throughout the Union". Accordingly, the provision envisages the establishment of a regime of protection which derives its substance from EU law. The Unitary Patent Package falls short of this.

a. Mismatch with the legal basis. The UP Regulation claims EU origin for the unitary patent, but disclaims EU law quality for its central features (see reason 9.a). This approach is not covered by the scope and purpose of Art. 118(1) TFEU. At the very least, the terms of the individual right granted under the UP Regulation (patentability, exclusivity, property) must be such as to enable the ECJ to exercise its judicial review. This is even more necessary since the unitary patent forms part of the rules governing the functioning of the Internal Market.

b. Evasion of the EU legislative process. Under the consistent jurisprudence of the ECJ, recourse must be had to legal bases where they are provided for in EU law. There is no legislative discretion as to what aspects of the unitary patent may be regulated in the UPCt Agreement vis-à-vis the UP Regulation. This concerns in particular the definition of the scope of exclusivity. Otherwise, the procedures and procedural safeguards provided for in the Treaties would be side-stepped and the principle of institutional balance compromised. A similar issue arises regarding the relationship between Art. 114 TFEU and the rules on infringement of the European patent in the UPCt Agreement. 
11. Exclusion of compulsory licenses through EU law primacy. Contrary to recital 9a of the UP Regulation, it is questionable whether national judicial or administrative authorities might grant national compulsory licenses in respect of the unitary patent. First, there is no competence left for Member States under Arts. 2(2) and 4 TFEU, should the matter be one of shared competences at all. Second, under the principles established by consistent jurisprudence of the ECJ, national authorities cannot invalidate or detract from acts of EU law and may defer their enforcement under very limited conditions only. The UP Regulation does not provide for any such exception. Finally, any granting of national compulsory licenses would quash the unitary effect, thus running against free trade rules.

12. Persisting incompatibility of the Unified Patent Court with EU law. The UPCt Agreement does not adequately address the concerns voiced by the ECJ in its Opinion 1/09 in terms of the EU law compatibility of the preceding court model. Although the UPCt is based on the example of the Benelux Court of Justice, its features significantly differ. Suffice it to mention that, unlike that of the Benelux Court, the UPCt's jurisdiction is not limited to preliminary references and that the UPCt is fully detached from the national legal systems (in fact replacing them). In addition, the issue of ECJ review of EPO decisions is not addressed in the proposal at all, thereby infringing the EU law principles of rule of law and of completeness of the system of judicial review.

In sum, notwithstanding the advanced political process, we believe it is indispensable to reconsider the content of the Unitary Patent Package afresh.

October 17, 2012

\author{
Reto M. Hilty \\ Thomas Jaeger \\ Matthias Lamping \\ Hanns Ullrich
}

\footnotetext{
${ }^{1}$ Proposal for a Regulation of the European Parliament and of the Council implementing enhanced cooperation in the area of the creation of unitary patent protection, $\operatorname{COM(2011)} 215$ final of 13 April 2011; as amended by Council doc. 17578/11 of 1 December 2011.

${ }^{2}$ Draft agreement on a Unified Patent Court and draft Statute, Council doc. 14750/12 of 12 October 2012.

${ }^{3}$ We do not address issues of fees or costs. However important, we do not possess the relevant data nor do they seem to have been established sufficiently yet.
} 
Annex \# 1: Major Documents in Chronological Order

\begin{tabular}{|c|c|c|}
\hline Year & Substantive law proposals & Court system proposals \\
\hline 1973 & $\begin{array}{l}\text { European Patent Convention (Convention on the Grant of European Patents (EPC), } 5 \\
\text { Oct. 1973) (in force since 1977) } \\
\text { - pre-grant and administrative procedures } \\
\text { - only selective harmonization of post-grant nat" patent law }\end{array}$ & \\
\hline 1975 & $\begin{array}{l}\text { 1st Community Patent Convention (Convention for the European Patent for the Com- } \\
\text { mon Market, } 15 \text { Dec. } 1975(1976 \text { OJ L 17, 1)) (not in force) } \\
\text { - EPO special unit administration } \\
\text { - unitary and autonomous Community patent granted by the EPO }\end{array}$ & $\begin{array}{l}\text { 1st Community Patent Convention (1976 OJ L 17, 1) (not in force) } \\
\text { - } \quad \text { nat'l courts and ECJ (today's EU trademark enforcement system) } \\
\text { - } \quad \text { competent for Community patents only } \\
\text { - } \quad \text { nationinary references } \\
\text { narts remain involved }\end{array}$ \\
\hline 1989 & $\begin{array}{l}\text { 2nd Community Patent Convention (Agreement relating to Community patents, } 15 \\
\text { Dec. } 1989(1989 \text { OJ L 401, 1)) (not in force) } \\
\text { - largely restatement of 1st Community Patent Convention } \\
\text { - new language regime }\end{array}$ & $\begin{array}{l}\text { 2nd Community Patent Convention (1989 OJ L 401, 1) (not in force) } \\
\text { - Common Appeal Court (incl. litigation protocol) } \\
\text { - } \quad \text { competent for Community patents only } \\
\text { - } \quad \text { nationinary courts remain involved }\end{array}$ \\
\hline 1992 & $\begin{array}{l}\text { Failure of Lisbon conference aimed at lowering the ratification threshold for the entry } \\
\text { into force of the Community Patent Convention (originally envisaged for Dec. 1991) }\end{array}$ & \\
\hline 2000 & $\begin{array}{l}\text { Community Patent Regulation (Proposal for a Council Regulation on the Community } \\
\text { patent (2000 OJ C 337E , 278)) (not in force) } \\
\text { - EPO administration } \\
\text { - unitary and autonomous Community patent granted by the EPO } \\
\text { - comprehensive set of rules on substantive patent law } \\
\text { London Agreement (Agreement on the application of Article } 65 \mathrm{EPC}, 17 \text { Oct. 2000) (in } \\
\text { force since 2008) } \\
\text { - no translation of European patents for States which have an official language in } \\
\text { common with the EPO languages } \\
\text { other States may require translation of claims into their official language }\end{array}$ & $\begin{array}{l}\text { Community Patent Regulation (2000 OJ C 337E, 278) (not in force) } \\
\text { - Community Intellectual Property Court } \\
\text { - } \quad \text { competent for Community patents only } \\
\text { - court preliminary references } \\
\text { - exclusive jurisdiction instead of national courts }\end{array}$ \\
\hline $2003 / 2004$ & $\begin{array}{l}\text { Amendments to Community Patent Regulation (Council Doc. No. 15086/03; Council } \\
\text { Doc. } 711904,8 \text { March 2004) (not in force) } \\
\text { - EPO administration } \\
\text { - } \quad \text { unitary and autonomous Community patent granted by the EPO } \\
\text { - comprehensive set of rules on substantive patent law }\end{array}$ & $\begin{array}{l}\text { Court Proposal } 2003 \text { (Proposal for a Council Decision conferring jurisdiction on the } \\
\text { Court of Justice in disputes relating to the Community patent, COM(2003)827 final; and } \\
\text { Proposal for a Council Decision establishing the Community Patent Court and concerning } \\
\text { appeals before the Court of First Instance, COM(2003)828 final) (not in force) } \\
\text { - Community Patent Court } \\
\text { - } \quad \text { classic EU court (Art. } 257 \text { TFEU), competent for Community patents only } \\
\text { - infringement and revocation, no EPO appeals or national preliminary references } \\
\text { exclusive jurisdiction instead of national courts }\end{array}$ \\
\hline
\end{tabular}




\begin{tabular}{|c|c|c|}
\hline $2003 / 2005$ & & $\begin{array}{l}\text { EPLA (Draft Agreement on the establishment of a European patent litigation system) } \\
\text { (not in force) } \\
\text { - EPO / EPO Member State initiative } \\
\text { - European Patent Court of Appeal } \\
\text { - } \quad \text { European patents only } \\
\text { - lwo instance court, full infringement and revocation jurisdiction, no EPO appeals, } \\
\text { - exclusive jurisdiction instead of nat'l courts }\end{array}$ \\
\hline 2009 & $\begin{array}{l}\text { Community Patent Regulation - General Approach (Council Doc. 16113/09) (not in } \\
\text { force) } \\
\text { - political breakthrough } \\
\text { - largely restatement of } 2004 \text { proposal }\end{array}$ & $\begin{array}{l}\text { EEUPCT (Draft Agreement on the European Community and Patents Court and Draft } \\
\text { Statute) (not in force) } \\
\text { - Community and European patents combined, participation extended to all EPO } \\
\text { states } \\
\text { - two instance court, full infringement and revocation jurisdiction, no EPO appeals, } \\
\text { limited ECJ preliminary references } \\
\text { - exclusive jurisdiction instead of national courts }\end{array}$ \\
\hline 2010 & $\begin{array}{l}\text { Regulation on Translation Arrangements (Proposal for a Council Regulation on the } \\
\text { translation arrangements for the European Union patent, COM(2010) } 350 \text { final) } \\
\text { - patent published in one EPO official language plus translations of the claims into the } \\
\text { other two EPO official languages } \\
\text { - further translations only in the case of court proceedings }\end{array}$ & \\
\hline 2011 & $\begin{array}{l}\text { Failure of negotiations over language arrangements } \\
\text { - } \quad \text { persisting opposition by Spain and Italy } \\
\text { Unitary Patent Regulation (Council Decision authorizing enhanced cooperation in the } \\
\text { area of the creation of unitary patent protection ( } 2011 / 167 / \mathrm{EU}) \text {; Proposal for a Regulation } \\
\text { implementing enhanced cooperation in the area of the creation of unitary patent protec- } \\
\text { tion (COM(2011) } 215 \text { final; as last amended by the Parliament in A7-0001/2012 of } 28 \\
\text { June } 2012) \text {; and Proposal for Council Regulation implementing enhanced cooperation in } \\
\text { the area of the creation of unitary patent protection with regard to the applicable transla- } \\
\text { tion arrangements (COM(2011) } 216 \text { final) } \\
\text { - EPO administration } \\
\text { - European patents with an identical scope of protection for the participating EU states } \\
\text { - } \quad \text { only } 25 \text { participating EU states (not Italy and Spain) } \\
\text { - } \quad \text { uncertain legal quality: unitary character, but not autonomous? }\end{array}$ & $\begin{array}{l}\text { ECJ Opinion 1/09 on EEUPCT Agreement } \\
\text { - } \quad \text { incompatibility with EU law } \\
\text { - } \quad \text { shift to BENELUX-type Court } \\
\text { Unified Patent Court (Draft Agreement on a Unified Patent Court and draft Statute } \\
\text { (Council Doc. 16741/11; latest Council Doc. 14268/12 of } 27 \text { Sep. 2012)) } \\
\text { - EU and European patents combined, but only for EU Member States } \\
\text { - two instance court, full infringement and revocation jurisdiction, no EPO appeals, } \\
\text { limited ECJ preliminary references } \\
\text { exclusive jurisdiction instead of national courts }\end{array}$ \\
\hline
\end{tabular}


Max Planck Institute for Intellectual Property and Competition Law

Annex \# 2: Table on Regime Fragmentation

\begin{tabular}{|c|c|c|c|c|c|c|c|c|c|c|c|c|c|c|c|c|c|c|}
\hline & \multicolumn{2}{|c|}{ Patent grant } & \multicolumn{2}{|c|}{ Revocation } & \multirow{3}{*}{$\begin{array}{c}\text { Scope } \\
\text { of } \\
\text { claims }\end{array}$} & \multirow{3}{*}{$\begin{array}{c}\text { Scope of } \\
\text { exclusivity }\end{array}$} & \multicolumn{2}{|c|}{ Exceptions } & \multicolumn{10}{|c|}{ Property aspects } \\
\hline & \multirow{2}{*}{$\begin{array}{l}\text { Autho- } \\
\text { rity }\end{array}$} & \multirow{2}{*}{$\begin{array}{l}\text { Le- } \\
\text { gal } \\
\text { ba- } \\
\text { sis }\end{array}$} & \multirow{2}{*}{$\begin{array}{l}\text { Autho- } \\
\text { rity }\end{array}$} & \multirow{2}{*}{$\begin{array}{l}\text { Legal } \\
\text { basis }\end{array}$} & & & \multirow{2}{*}{$\begin{array}{l}\text { Exceptions } \\
\text { in general }\end{array}$} & \multirow[t]{2}{*}{ Exhaustion } & \multicolumn{2}{|c|}{ Transfer of right } & \multicolumn{2}{|c|}{ Licensing } & \multirow{2}{*}{$\begin{array}{l}\text { Law } \\
\text { applicable } \\
\text { to Securi- } \\
\text { ties }\end{array}$} & \multicolumn{2}{|l|}{ Execution } & \multicolumn{3}{|c|}{ Compulsory licenses $^{2}$} \\
\hline & & & & & & & & & substantive & territorial & $\begin{array}{l}\text { Patent } \\
\text { law }\end{array}$ & $\begin{array}{l}\text { Contract } \\
\text { law }\end{array}$ & & Authority & $\begin{array}{l}\text { Applicable } \\
\text { law }\end{array}$ & Territory & Authority & $\begin{array}{l}\text { Applicable } \\
\text { law }\end{array}$ \\
\hline $\begin{array}{l}\text { Nat'l } \\
\text { patents } \\
\text { (1 state) }\end{array}$ & Nat'l & Nat'1 & Nat'1 & $\begin{array}{l}\text { Nat'1 } \\
\text { law }\end{array}$ & $\begin{array}{l}\text { Nat'l } \\
\text { law }\end{array}$ & Nat'll law & Nat'll law & EU law & Nat'll law & $\begin{array}{l}\text { Nat'l } \\
\text { territory }\end{array}$ & Nat'1 & $\begin{array}{l}\text { Acc. to } \\
\text { contract } \\
\text { or int'l } \\
\text { private } \\
\text { law }\end{array}$ & Nat'1 & Nat'1 & $\begin{array}{l}\text { Nat'll/ } \\
\text { conflicts } \\
\text { law }\end{array}$ & Nat'l & Nat'll & Nat'l \\
\hline $\begin{array}{l}\mathbf{E P C}^{3} \\
\text { (38 states) }\end{array}$ & EPO & EPC & Nat'l & $\begin{array}{l}\text { Art. } \\
138 \\
\text { EPC }^{5}\end{array}$ & EPC & Nat'llaw & Nat'll law & EU law & Nat'll law & $\begin{array}{l}\text { Nat'l } \\
\text { territories }\end{array}$ & Nat'l & $\begin{array}{l}\text { Acc. to } \\
\text { contract } \\
\text { or int'l } \\
\text { private } \\
\text { law }\end{array}$ & Nat'1 & Nat'l & $\begin{array}{l}\text { Nat'll/ } \\
\text { conflicts } \\
\text { law }\end{array}$ & Nat'l & Nat'l & Nat'l \\
\hline 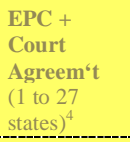 & EPO & EPC & UPCt & $\begin{array}{l}\text { Art. } \\
138 \\
\text { EPC }^{5}\end{array}$ & EPC & $\begin{array}{l}\text { Art. 14f } \\
\text { and } 14 \mathrm{~g} \\
\text { Court } \\
\text { Agreem't }\end{array}$ & $\begin{array}{l}\text { Art. } 14 \mathrm{~h} \\
\text { and } 14 \mathrm{i} \\
\text { Court } \\
\text { Agreem't }{ }^{1}\end{array}$ & EU law & Nat'll law & $\begin{array}{l}\text { Nat'l } \\
\text { territories }\end{array}$ & Nat'1 & $\begin{array}{l}\text { Acc. to } \\
\text { contract } \\
\text { or int'l } \\
\text { private } \\
\text { law }\end{array}$ & Nat'1 & Nat'l & $\begin{array}{l}\text { Nat'll/ } \\
\text { conflicts } \\
\text { law }\end{array}$ & Nat'l & Nat'1 & Nat'l \\
\hline $\begin{array}{l}\text { EPC + } \\
\text { Court } \\
\text { Agreem't } \\
\text { (with opt- } \text { out) } \\
\text { out } \\
(1 \text { to } 27 \\
\text { states) }\end{array}$ & EPO & EPC & Nat'l & $\begin{array}{l}\text { Art. } \\
138 \\
\text { EPC }^{5}\end{array}$ & EPC & $\begin{array}{l}\text { Art. } 14 \mathrm{f} \\
\text { and } 14 \mathrm{~g} \\
\text { Court } \\
\text { Agreem't? }\end{array}$ & 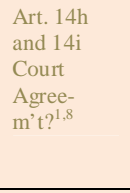 & EU law & Nat'll law & $\begin{array}{l}\text { Nat'1 } \\
\text { territories }\end{array}$ & Nat'1 & $\begin{array}{l}\text { Acc. to } \\
\text { contract } \\
\text { or int'l } \\
\text { private } \\
\text { law }\end{array}$ & Nat'l & Nat'1 & $\begin{array}{l}\text { Nat'll/ } \\
\text { conflicts } \\
\text { law }\end{array}$ & Nat'l & Nat'1 & Nat'1 \\
\hline $\begin{array}{l}\text { EPC + } \\
\text { Patent Reg. } \\
\text { + Court } \\
\text { Agreem't' } \\
(13 \text { to } 27 \\
\text { states })^{10}\end{array}$ & EPO & EPC & UPCt & $\begin{array}{l}\text { Art. } \\
138 \\
\text { EPC }^{5}\end{array}$ & EPC & $\begin{array}{l}\text { Art. } 6 \text { and } \\
7 \text { Patent } \\
\text { Reg. }\end{array}$ & $\begin{array}{l}\text { Art. } 8 \\
\text { Patent } \\
\text { Reg. }\end{array}$ & EU law & $\begin{array}{l}\text { One nat'l } \\
\text { regime } \\
\text { (Art. } 10 \\
\text { Patent } \\
\text { Reg. })^{11}\end{array}$ & $\begin{array}{l}\text { Territories } \\
\text { of the } \\
\text { enhanced } \\
\text { coop. (13 } \\
\text { to } 25 \\
\text { states) }\end{array}$ & $\begin{array}{l}\text { One } \\
\text { nat'l } \\
\text { regime } \\
\text { (Art. } \\
10 \\
\text { Patent } \\
\text { Reg. })^{11} \\
\end{array}$ & $\begin{array}{l}\text { Acc. to } \\
\text { contract } \\
\text { or int'l } \\
\text { private } \\
\text { law }\end{array}$ & $\begin{array}{l}\text { One nat'l } \\
\text { regime } \\
\text { (Art. 10 } \\
\text { Patent } \\
\text { Reg.) }\end{array}$ & Nat'1 & $\begin{array}{l}\text { Nat'll/ } \\
\text { conflicts } \\
\text { law }\end{array}$ & Nat'l & Nat'l & Nat'l \\
\hline $\begin{array}{l}\text { Benchmark } \\
\text { Internal } \\
\text { Market } \\
\text { (27 states) }\end{array}$ & EPO & EPC & UPCt & $\begin{array}{l}\text { Art. } \\
138 \\
\text { EPC }^{5}\end{array}$ & EPC & EU law & EU law & EU law & EU law & EU-wide & $\mathrm{EU}$ & EU law & $\mathrm{EU}^{12}$ & Nat'l & $\begin{array}{l}\text { EU con- } \\
\text { flicts rule }\end{array}$ & $\mathrm{EU}$ & UPCt & EU law \\
\hline
\end{tabular}

Colors indicate which of 4 regimes is applicable: Nat'l (red) / EPO (green) / EU (purple) / Unitary patent package (brown). Black = other / not applicable.

$1 \quad$ Prior user right currently foreseen for European patents only, not for unitary patents.

EPC applies to non-EU states, states remaining outside the enhanced cooperation (ES + IT) and while transitional period applies according to Art. 58 (1) 2011 Court Agreement.

Even EU Member States not part of the enhanced cooperation for the creation of the Unitary patent may participate in the Court Agreement in relation to European patents.

Directly applicable or applicable upon transformation into nat' $1 /$ EU law.

Cf. Art. 58 (3) 2011 Court Agree ment: "... holders of European patents or patent applications granted or applied for prior to the date of entry into force [...] shall have the possibility to opt-out from the exclusive

Court Agreent lapplies olly

Patent Reg. and Court Agreem't apply as a package, but only where minimum threshold of 13 ratifications is reached (Art. 59 (1) 2011 Court Agreement)

11 One nat' regime per patent (law of the Member State of the patent holder or German law). Governs the patent statute only. Beyond patent statute: Choice of law applie.
12
IP contract law is currently not harmonized on the EU level, but such harmonization appears beneficial de lege ferenda. 


\section{Annex \# 3: Court System Illustration}
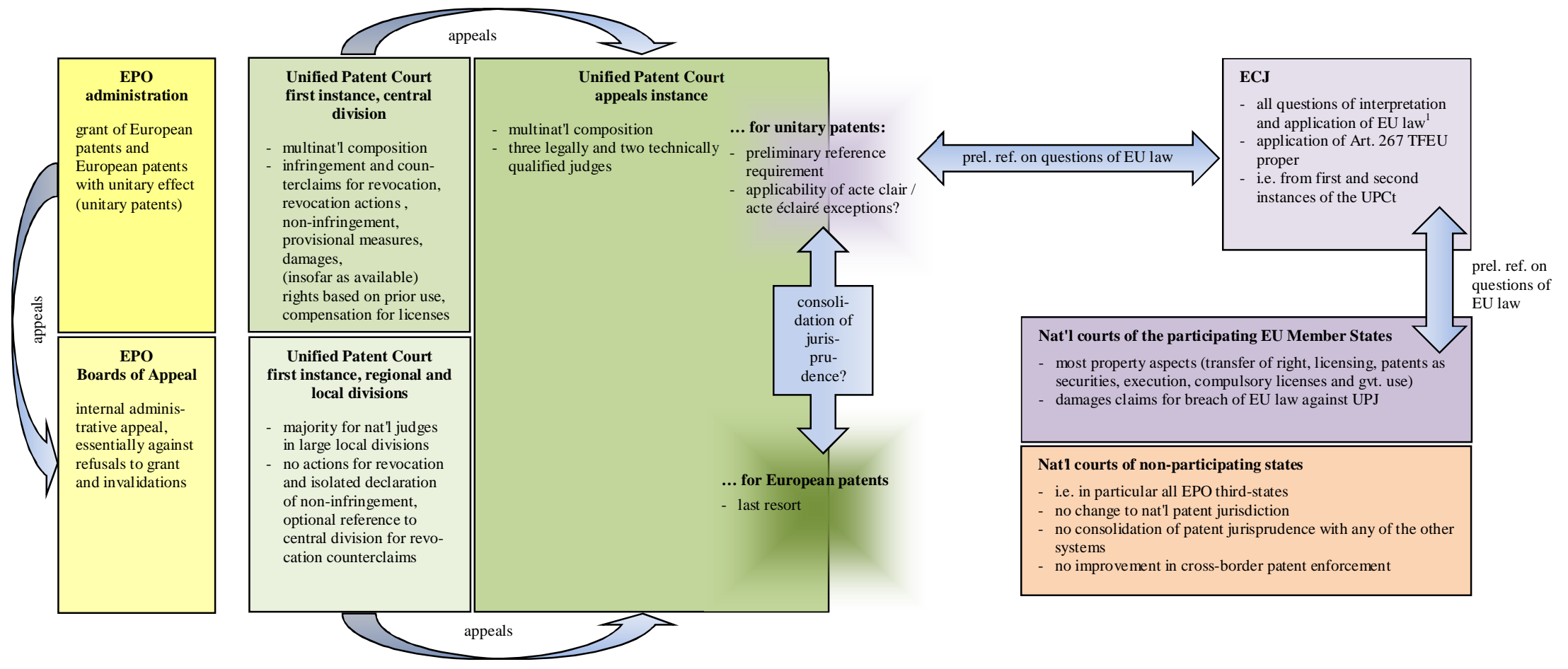

Four separate jurisdictional systems for patents in Europe:

\begin{tabular}{|c|c|c|c|}
\hline $\begin{array}{c}\text { System 1: } \\
\text { EPO }\end{array}$ & $\begin{array}{c}\text { System 2: } \\
\text { UPCt for } \\
\text { European } \\
\text { patents }\end{array}$ & $\begin{array}{c}\text { System 3: } \\
\text { UPCt + ECJ } \\
\text { + nat' courts } \\
\text { for EU } \\
\text { patents }\end{array}$ & $\begin{array}{c}\text { System 4: } \\
\text { non- } \\
\text { participa- } \\
\text { ting nat'1 } \\
\text { courts for } \\
\text { European } \\
\text { patents }\end{array}$ \\
\hline
\end{tabular}

1. Questions of EU law = any question relating to the interpretation or application of primary or secondary EU legislation, general principles of EU law or fundamental rights, irrespective of the type of proceedings (infringement, revocation, licensing dispute etc....) 